\title{
PDE4DIP wt Allele
}

National Cancer Institute

\section{Source}

National Cancer Institute. PDE4DIP wt Allele. NCI Thesaurus. Code C97719.

Human PDE4DIP wild-type allele is located in the vicinity of $1 q 12$ and is approximately $240 \mathrm{~kb}$ in length. This allele, which encodes myomegalin protein, is involved in the localization of phosphodiesterase activity. A chromosomal translocation t(1;5)(q23;q33)

of this gene and the PDGFRB gene is associated with myeloproliferative disorder associated with eosinophilia. 